\title{
Chapter 6 \\ Migrant Care Labour, Covid-19, \\ and the Long-Term Care Crisis: Achieving \\ Solidarity for Care Providers \\ and Recipients
}

\author{
Lena Gahwi and Margaret Walton-Roberts
}

\subsection{Introduction}

The coronavirus pandemic has exacerbated and accentuated an ongoing crisis of care. An historic lack of investment in care, especially in areas of elder care, has resulted in long-term care (LTC) facilities being the epicentre of the pandemic in various nations. This chapter provides some context regarding the care crisis in LTC facilities in Ontario, Canada, particularly its relationship with the type and skill mix of labour, including the degree to which immigrant workers are represented in this sector. Combined with persistent staff shortages, the sustainability of long-term care was an international issue of concern prior to the pandemic. Half the nations belonging to the Organisation for Economic Co-operation and Development (OECD) have seen population ageing exceed growth in the number of LTC workers (OECD and European Union, 2013). When the pandemic arrived, the conditions of those working and living in LTC facilities became a key issue of public concern in many countries as Covid-19 infection and mortality rates increased. For example, one-third of all coronavirus deaths in France and $75 \%$ in Canada (as of November 2020) have been in care homes (Walsh \& Semeniuk, 2020; National Institute of Ageing, n.d.). As with other epidemics, the coronavirus exposed how poor working conditions undermine infection control protocols and make workers and residents vulnerable to infection. Covid-19 has reinforced arguments about the need to invest in the care provided in LTC facilities by also improving conditions of work and enhancing the skills composition of workers.

\footnotetext{
L. Gahwi

Master of International Public Policy, Balsillie School of International Affairs, Wilfrid Laurier University, Waterloo, ON, Canada

M. Walton-Roberts $(\bowtie)$

Geography and Environmental Studies Department, Wilfrid Laurier University,

Waterloo, ON, Canada

e-mail: mwaltonroberts@wlu.ca
} 
We begin this chapter with some conceptual reflections on elder care as a matter of social justice and ethics in terms of those needing and providing care. We review how these ethical and social justice concerns take on a specific global dimension because of the transnationalisation of care, or the care provisioning function of global care chains. Next, we examine some international comparisons regarding the LTC funding models for contextual reference to understand the structural conditions within which this globally-sourced workforce is positioned. We then highlight two significant contributing factors to the current LTC crisis using Ontario, Canada, as an example: first, the role of the private sector and the unsustainable extraction of profits from this service and, second, the gendered and racialised devaluing of migrant labour so essential to the sector.

\subsection{Long-Term Care as a Social Justice Matter}

Policy failures in the provision of quality long-term care and the devaluating of the labour of those providing care are, at their root, ethical social justice issues. This was clearly articulated in a 2002 World Health Organisation-sponsored panel to consider 'ethical choices in long term care: what does Justice require?' In light of the coronavirus pandemic's impact, it is helpful to revisit that document and its argument that '[a]ny societal commitment of resources to build institutions needs to be accompanied by a commitment to the basic human dignity of those who will use them' (WHO, 2002, ix). The WHO report's summary observed that the limits of how care was being organised were already being reached at that time. The report encouraged states to consider 'alternatives that do not depend on care based exclusively on either affection or market principles' (ibid., 10). To review the issue, the WHO commissioned philosophy and political theorist Martha Nussbaum to consider the ethics underlying long-term care, arguing that 'the problem of care is a complicated logistical problem for any society. It is also, most emphatically, an ethical problem...' (ibid., 34).

Nussbaum's recommendations included building a universal framework to underpin the ethics of care that moves away from the social contract model of justice, since this model assumes all actors are rational bargainers and have the necessary competencies to bargain equally. Her suggested way forward is to first include care as a primary good - a basic need that all humans require at some stage of their life - and change the idea of primary goods to that of capabilities, as this allows for a more accurate comparison of quality of life across diverse contexts. Nussbaum argues that such a model results in a process whereby people's 'asymmetrical needs are treated as part of their human dignity, rather than as large social costs to be borne' (ibid., 63). This echoes Martha Albertson Fineman's (2008) work on vulnerability and the human condition, in that vulnerability is recognised as a universal constant of the human condition, one that necessitates models of state responsibility and responsiveness. 
An interesting aspect of the 2002 WHO report on the ethics of care reveals an early recognition of the significant of what Yeates (2011) later termed the transnationalisation of care, or the global organisation of care-giving: 'Much of the caregiving in wealthy and developed countries is being provided by care workers, nursing professionals, and others who have migrated from impoverished and developing countries. While these workers may experience economic benefit, they also create gaps in their own families and communities. Arguably, wealthy nations incur a debt in this exchange that somehow needs to be repaid. Likewise, it is reasonable to ask if the multinational corporations that depend on the natural and human resources in developing countries have a responsibility to fill the gaps in caregiving they help to create' (WHO, 2002, x).

The WHO report acknowledged the consequences of this global provisioning of care in terms of the problems sending nations face in servicing it, and more importantly, the responsibilities that should be incurred on the part of receiving nations who benefit from it. The reality today is that health and long-term care provision have become transnationalised as care (especially elder care) is effectively outsourced by wealthy countries through the incorporation of migrant workers whose rights and benefits are often constrained through state and labour market restrictions (Ormond \& Toyota, 2018).

\subsection{Global Care Chains and the Transnationalisation of Care Work}

The reality of this transnationalisation of care has been explored through the idea of Global Care Chains: a series of global connections, or a chain, based on the paid and unpaid work of caring (Hochschild, 2015; Yeates, 2011). These chains allow for the extraction of care based on the exploitation of multiple divisions including gender, ethnicity, class, and uneven development. The devaluing of feminised skills is a key feature of these global migration processes under these conditions of globalising care (Kofman, 2014; Yeates, 2009). Aligned to this, the sovereign practice of granting or limiting rights (through state and non-state mechanisms) has the effect of further stratifying feminised care workers into low-paid precarious positions by governing their mobility through various filtering processes (Mezzadra \& Neilson, 2013). High-income nations have seen women move into the workforce without states providing social welfare systems to care for children and the elderly (that is, the unpaid labour that women traditionally provided) (Browne \& Braun, 2008). In these wealthier nations, care work has effectively been outsourced: from being the responsibility of women within the household, it is now racialised women from developing nations who leave their own families to care for others. This care labour is both commoditised and devalued, with compensation far below the actual value of the care provided. This process has been captured through the concept of 'global care chains'. 
The WHO has referred to migrant women care workers as 'a cushion for states that lack adequate public provision for long-term care, childcare and care for the sick' (WHO, 2017, 9). It identifies a 'care paradox', wherein migrant women work to fulfil the growing need for care workers in high-income and middle-income nations and strengthen weak health systems, while lacking health services themselves (Hennebry \& Walton-Roberts, 2019). This paradox is highlighted in the challenging role visible minority and migrant women play as care providers and care aides in LTC homes, typically working in low-paid positions deemed 'low-skilled' while actually performing complex and essential services for vulnerable dependent populations (Browne \& Braun, 2008).

Internationally, the number of migrant care workers in LTC in core nations is growing. In the United States, as of 2011, one in four care workers in LTC were migrants - a 5\% increase from 2005 (Browne \& Braun, 2008; OECD, 2015). In the United Kingdom, the number of migrant care workers more than doubled between 2001 and 2009, from 7\% to 18\% (Shutes, 2011). Currently, the UK's social care sector faces significant challenges in a post-Brexit context since under the new immigration policy rules care workers do not earn enough to qualify for immigration, yet the sector already relies on over 350,000 migrant workers with $8 \%$ of vacancies unfilled (Economist, 2020). A similar trend can be found in Canada, with research suggesting migrant workers represent up to $50 \%$ of LTC caregivers in certain provinces (Estabrooks et al., 2014). According to the 2016 census, visible minority workers are overrepresented as nursing home employees across all Canadian provinces (Multicultural Meanderings, 2019; Turcotte \& Savage, 2020).

The demographic shift in who performs care labour in high-income nations is evident, and racial as well as gendered intersectional prejudice cannot be disassociated from the crisis of care in LTC homes and facilities. In OECD nations, $90 \%$ of LTC workers are women and approximately $45 \%$ of them work part-time (OECD, 2019). What is consistent across the literature is that care work is socially regarded as work to which women are naturally predisposed; it is thus essentialised as feminine labour and considered unskilled, which facilitates its devaluation (Browne \& Braun, 2008; Horton, 2019). Employers can naturalise this labour market segmentation by reproducing ideas about certain racial and cultural backgrounds making migrant workers better at caring for older populations and less likely to complain about strenuous or difficult work conditions (Atanackovic \& Bourgeault, 2013). Employers often believe that migrant workers are more likely to be willing to work longer hours and are more flexible with shifts (Ruhs \& Anderson, 2013). Immigration and employment policies, alongside structural forms of gendered and racial discrimination, create precarious employment conditions for immigrant workers in this sector (Robillard et al., 2018). Restrictive immigration status combines with these labour market contexts to make it easier to retain immigrants in jobs with working conditions non-migrants would not tolerate. Additionally, immigrants might be attractive as 'high-quality workers for low-skilled jobs', especially in non-regulated occupations where skills can be determined by the employer and reflect their interests, including what they want to pay and how they want people to behave (Ruhs \& Anderson, 2013). These preconceptions can lead to problematic relationships 
between employers and workers, with employers limiting workers' options to access greater rights (ibid.). Employers can leverage the precarious status of immigrant caregivers to pay lower wages and maintain poor working conditions (Goldring \& Landolt, 2013). Central to this issue of ethics, then, is assessing and appreciating how the role of migrant caregivers within core nations' systems of elder care provision might be shaped by the organisation and financing of this sector. We begin with consideration of the policy dimensions of LTC and how various states have attempted to fund and provide it.

\subsection{Financing Long-Term Care and the Rise of Privatisation}

Part of the larger debate about the crisis of elder care in high-income nations is how LTC should be financed. What is consistent across different nations is the sheer cost of LTC. In the next 30 to 40 years, high-income states will need to double their spending in the LTC sector to keep up with ageing populations. High-income nations face ageing populations in need of care, yet they often lack the necessary workforce to fulfil their needs. In France, for example, the number of individuals over 65 is set to rise by $40 \%$ by the year 2030 (Chevreul \& Berg Brigham, 2013). In Canada, those over 65 make up $15.6 \%$ of the population, and this demographic is set to grow to $23 \%$ by 2030 (Government of Canada, 2014). The European Commission estimates that the EU will need to increase spending on LTC from $1.8 \%$ of GDP to $3.6 \%$ by 2060 (Glinskaya \& Feng, 2018).

There are different political interests and approaches to the financing of LTC. In Canada, the US, and the UK, there has been growth in private ownership and operation of LTC facilities. In Alberta, for example, there has been a recent push toward selling two publicly-owned LTC homes to cut costs, increase revenues, and open up more beds (Vernon, 2020). According to the Ontario Long-Term Care Association, $59 \%$ of LTC facilities in Ontario are privately owned, $25 \%$ are non-profit, and $16 \%$ are public (OLTCA, n.d.). International comparative research has also shown how privatisation pressures in the LTC sector have increased across several high-income nations as well as revealed the resulting negative influence privatisation has on the quality of work and care in the sector (Armstrong \& Armstrong, 2019).

Despite the various approaches to funding LTC across the globe, these are generally unsustainable as the world population continues to age. For example, a recent special report on dementia in The Economist used the tagline: 'Nowhere in the world is ready to cope with the global explosion of dementia' (Economist, 2020, 3). Table 6.1 demonstrates the different types of LTC financing being used by various states. In Germany, Japan, and South Korea, citizens must 'opt in' to mandatory insurance schemes to help finance their stay in LTC (The Federal Ministry of Health, Germany, 2017). In the case of Germany, insurance covers part of the costs for long-term living, the rest is paid for through out-of-pocket (OOP) expenditures and sometimes another social program (ibid.). In the German case, LTC is not specifically publicly funded and therefore is not means-tested (Nadash et al., 2011). 
Table 6.1 Global approaches to funding LTC

\begin{tabular}{|c|c|c|c|c|c|c|}
\hline \multirow{2}{*}{ Publicly funded/subsidise } & Ontario & Germany & Japan & South Korea & France & UK \\
\hline & & & & & & \\
\hline Mandatory insurance & & & & & & \\
\hline Means-tested $^{\mathrm{a}}$ & & & & & & \\
\hline Out-of-pocket expenses & & & & & & \\
\hline
\end{tabular}

ai.e., access based on need or only the desire to go into a long term-care facility

Sources: based on information from Glinskaya and Feng (2018), Chevreul and Brigham (2013) and OECD and European Union (2013)

In Japan, LTC is funded by the national government; the insurance premiums paid by citizens and access to LTC in Japan are means-tested and dependent on age and ability (Glinskaya \& Feng, 2018). Similarly, in Korea the system is financed through government subsidies, mandatory premium payments by the general population that accounts for $60-65 \%$ of the cost, and OOP spending by those using the facilities. Due to the programme being partially publicly funded, however, it is not meanstested and universally covers citizens over 65 (ibid.). In France, LTC is publicly funded through taxation and has achieved around $70 \%$ coverage. The levels of coverage for the French programme are heavily income-adjusted: those with the lowest income do not make any co-payments to receive access to the programme whereas those with higher incomes contribute up to $90 \%$ in co-payments (Chevreul \& Berg Brigham, 2013). In the UK, LTC is also publicly funded, however, patients face means-testing and some are also required to contribute to co-payments for living in the facilities, with a lifetime cap of $£ 72,000$ (OECD and European Union, 2013).

In the UK, many LTC facilities are privately owned and managed. Small private companies often rely on banks to finance the LTC homes they own, and this type of funding is often stricter and more difficult to obtain. However, larger private organisations that own multiple LTC facilities have recently shifted to private equity firm investment which, compared to public markets or banks, is more tolerant of high levels of debt (Horton, 2019). As a result, private equity firms such as Blackstone or Alliance are investing money in poorly-managed and debt-encumbered LTC homes that would be deemed risky investments. This need for increased private investment is a result of government austerity measures and decreased public ownership and funding of LTC facilities. The private companies that own LTC facilities then choose to open branches that seek to serve poor and underserved communities to maintain their eligibility to receive available public funding (Horton, 2019). These private equity firms make a profit through the buying, selling, and investing in real estate assets not through the daily business of managing the facilities and the care of patients. LTC in the UK is regulated by the state through a quality assurance framework. Facilities are required to register with the Care Quality Commission and fulfil the requirements outlined by the commission (OECD and European Union, 2013). Thus both public and private facilities are expected to meet the same standards. However, the opposing interests of private financial interests and government 
requirements make the operation of LTCs complex, and effective regulatory oversight and enforcement necessary, but often insufficient. Research suggests that nonprofit providers offer higher-quality care than for-profit providers (Barron \& West, 2017).

Similar LTC issues are faced in Ontario, and these have been further highlighted by the current Covid-19 crisis. LTC facilities are run by non-profit organizations, private companies, or public municipalities (OLTCA, n.d.). These facilities must be licensed and funded by the Ministry of Health and Long-Term Care. Facilities can be privately run and owned, but the fees of individual residents are publicly funded, with some out-of-pocket costs or co-pays (ibid.). Ontario's provincial government has failed to fund LTC appropriately. Between 2011 and 2018, there was a 0.8\% increase in available beds in public facilities, while the waitlist for beds almost doubled in number (see Fig. 6.1) (Gibson, 2019).

Ontario's current Progressive Conservative government cut funding to LTC facilities before the Covid-19 crisis. On 21 April 2020, the Ontario Health Coalition published an update on the pandemic, stating that there had been outbreaks in 155 LTC homes, with 2687 confirmed cases and at least 341 deaths (Ontario Health Coalition, 2020a). A report published by the Ontario Health Coalition on 6 May 2020, showed that the rate of Covid-19 deaths in private care homes were double those in publicly-funded homes (see Fig. 6.2) (Ontario Health Coalition, 2020b). Pat Armstrong et al. (2020) assert that Ontario's push to privatise LTC is in direct contrast to evidence against increased private ownership of health services.

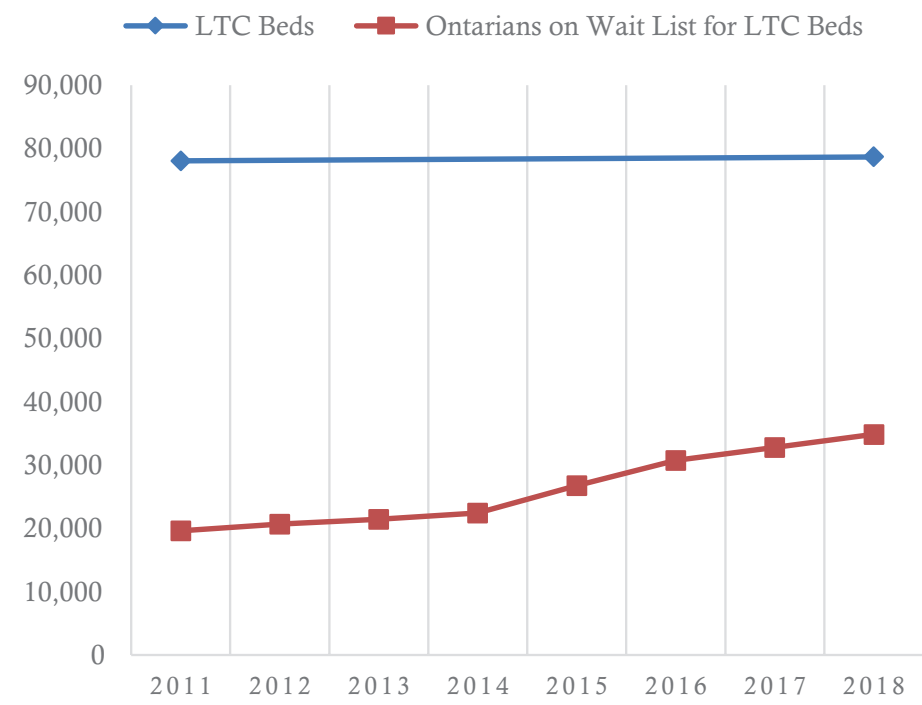

Fig. 6.1 Number of LTC beds in Ontario versus number of Ontarians on the wait list. (Source: Based on data from 'Long-Term Care Homes Program: A Review of the Plan to Create 15,000 New Long-Term Care Beds in Ontario', Financial Accountability Office of Ontario, 2019) 


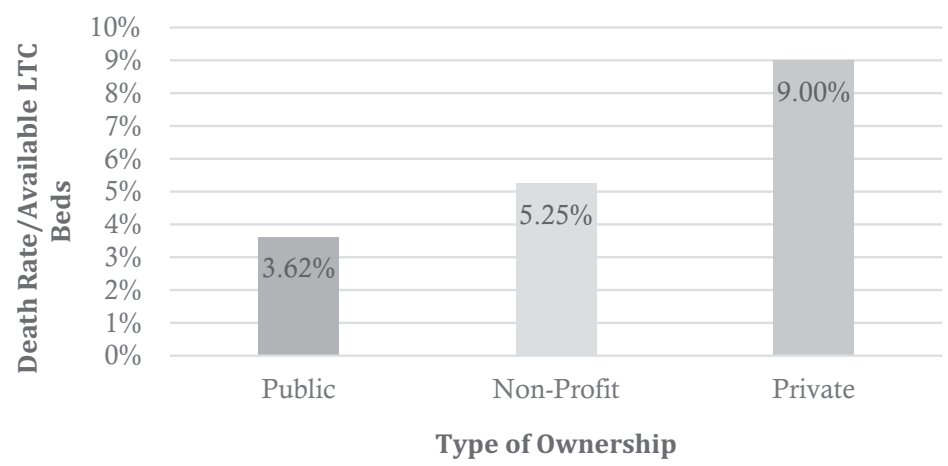

Fig. 6.2 Ontario death rates per total LTC beds available, by type of ownership. (Source: Based on OLTCA data)

Careful analysis of the consequences of privatising LTC provision indicates the centrality of legislation that allows for the devaluing and marginalisation of workers in the sector. Evidence from Ponder et al. (2020) regarding early 2000s legislation by British Columbia's Liberal government to increase private sector investment in LTC has shown that minimising labour costs is central to such measures, which allow for strategies like 'contract flipping' that resist unionisation and continually depress labour costs and restructure work conditions. This significance of labour 'flexibility' led Ponder et al. $(2020,9)$ to argue that 'the ability granted to private sector actors by Bill 94 to reduce labour costs associated with participating in the sectoral bargaining model appears to have been crucial for motivating private investment in the nursing home sector'. Ponder et al. (ibid.) further highlight key consequences of these structural transformations for workers in the sector in terms of a degradation of management-worker relations, lower remuneration and loss of benefits, chronic changes in the working-care environment due to staff shortages and turnover (among other issues), and moral distress (in care workers' inability to report their concerns about residents' welfare).

\section{5 'Conditions of Work are the Conditions of Care': Ontario and the LTC Crisis During the Pandemic}

The preconditions contributing to the crisis in LTC facilities during the coronavirus pandemic include a lack of investment in elder care (and, by extension, to the problematic dependence on the private sector), the underdevelopment of employee skills and training, and poor working conditions for those employed in the sector. An international research network focused on quality of care provided to those with complex medical cases highlighted five key areas for improvement in LTC facilities based on the weaknesses exposed by Covid-19 (Hirdes et al., 2020). First, the need to match clinical resources to the needs of LTC residents, who have increasingly 
complex medical conditions but receive less nursing care than residents in hospitals and continuing care facilities. Second, the need for collaboration to improve quality of care and quality of life through common performance measures, knowledge exchange, and transparency in reporting and benchmarking. Third, the chaos and lack of information and preparedness in some facilities that emerged during the pandemic reveals the importance of improving the evidence base across the sector, which entails the use of standardised assessment instruments, real-time reporting systems, and better in-house analytical and assessment capacity. Fourth, LTC facilities need to be supported through better pandemic and emergency preparedness planning since in some countries (including Canada) LTC homes were not included in hospital pandemic planning protocols, procedures for infection control, or PPE stock requirements. Fifth, a recommendation to improve LTC employees' quality of work life since staffing is a key factor in some of the most adverse outcomes in LTC facilities because of the part-time, precarious, and insecure nature of employment for the majority of care workers. Clearly work conditions in the sector are seen as centrally important in the overall quality of care provided (Barken and Armstrong, 2017).

\subsection{Migrant Care Labour in LTC: Status, Skill Mix, and Conditions of Work and Care}

During the pandemic it became apparent that essential workers in the care sector disproportionality included more immigrants - especially women and often racialised workers. Turcotte and Savage (2020) show that between 1996 and 2016, the proportion of immigrants in the occupations of nurse aide, orderly, and patient service associate rose from 22 to $36 \%$. Across Canada the share of immigrants in these occupational groups ranges provincially from $2.9 \%$ in Newfoundland and Labrador to $51.6 \%$ in Alberta, and is more concentrated in Canada's largest cities, ranging from $47.8 \%$ in Montreal to $78.7 \%$ in Toronto. In terms of gender, the majority (often around $80 \%$ ) are women, with an overrepresentation of Black, Filipino, and South Asian ethno-national communities. Indicatively, Black women represent $26 \%$ of the care aide occupational group but less than $4 \%$ of all immigrant workers in other occupations. The sector also includes a rather highly educated group of workers, especially in the most recently arrived immigrant cohorts, with $45 \%$ of the most recent immigrants in these occupations having at least a Bachelor's degree. Of those recent immigrants with a university degree working in the sector, $44 \%$ had completed their studies in a health-related field; of these, two-thirds held nursing degrees. Turcotte and Savage (ibid.) report on immigrants in Canada (those granted citizenship or permanent residence) so there may, in fact, be a larger number of migrant workers in Canada's care sector when we consider the possible inclusion of temporary migrants - among them the more than 640,000 international students and 55,000 asylum claimants who are granted permission to work. For example, during 
the pandemic it became evident that asylum seekers in Montreal were working as LTC care aides, and they have received public support and calls for their status to be converted to permanent residence (Seidle, 2020). In August 2020 the Federal government announced a temporary measure providing a pathway to permanent residency for asylum claimants who were working in the healthcare sector during the Covid-19 pandemic (Government of Canada, 2020).

Working conditions in Ontario LTC facilities are especially dire, with studies indicating insufficient training for caregivers, rigid hierarchies within facilities, understaffed homes, and poor levels of care (Barken \& Armstrong, 2017). Pat Armstrong et al. (2020) contend that years of governments deprioritising the sector have rendered those in care much more vulnerable to Covid-19.

In Canada residential care for those in need of assistance with daily living includes a range of facilities, many of which are assessed and monitored using the Continuing Care Reporting System (Canadian Institute for Health Information, n.d.). The clinical data standard for CCRS uses a reporting system developed by interrai (n.d.), an international research network. There is a range of residential facilities, varying from short-term, post-acute care in skilled nursing facilities to long-term, chronic care and nursing home institutional settings (see Table 6.2). The degree of clinical care provided and the skill mix of workers differs across these institutions and can include physicians, nursing staff (registered nurses and registered practical nurses), other allied health professionals, and personal support workers (PSWs). The latter are unregulated care providers with no defined scope of practice, whose role has evolved to include functions formerly provided by regulated health professionals. As the intensity of care needs increases, the mix of workers includes more regulated professionals, but it is clear that PSWs are essential to most residential care facilities. Research has indicated that these factors, combined with the variation in PSW education and employment standards, has significant implications for patient safety and quality of care (Kelly \& Bourgeault, 2015; Saari et al., 2018). PSWs in this sector are low-paid, overworked, mostly part-time, and often piece together two or more jobs across many facilities (Sproule, 2020). The pandemic has exposed how migrants, including asylum seekers, are working as PSWs in essential fields and how they have been at the forefront of the fight against Covid-19 in long-term residential care (LTRC) facilities (Seidle, 2020).

\subsection{Bearing Witness to the Crisis in Pandemic Times}

For Ontario the reality of the crisis in LTC became news in April 2020 when Canadian troops were deployed to five facilities in Greater Toronto to support staff and contain patient infection (Raymond, 2020). The Canadian Armed Forces Joint Task Force issued a fairly damning report on 20 May 2020 on the conditions found in LTC homes during their deployment. Staffing was consistently mentioned as a key issue at all five LTC facilities where the military intervened, with 60 mentions in the 15-page report; problems with management issues appeared almost as 
Table 6.2 Types of care facilities, description of care, and workers employed

\begin{tabular}{l|l|l}
\hline $\begin{array}{l}\text { Type of care } \\
\text { facility }\end{array}$ & Description of care provided & $\begin{array}{l}\text { Mix of workers } \\
\text { employed }\end{array}$ \\
\hline $\begin{array}{l}\text { Independent } \\
\text { living } \\
\text { communities }\end{array}$ & $\begin{array}{l}\text { Housing communities for seniors who are able to care } \\
\text { for themselves but wish to be around others of the } \\
\text { same age. Does not necessarily include in-home } \\
\text { assistance, but individuals can hire home-care } \\
\text { workers to assist them if needed. }\end{array}$ & $\begin{array}{l}\text { Do not employ medical } \\
\text { workers or PSWs, but } \\
\text { these can be hired } \\
\text { separately by } \\
\text { individuals. }\end{array}$ \\
\hline $\begin{array}{l}\text { Assisted living } \\
\text { facilities }\end{array}$ & $\begin{array}{l}\text { Facilities that provide daily assistance to seniors who } \\
\text { require help with cooking, cleaning, eating or } \\
\text { personal hygiene, but do not require intensive medical } \\
\text { care. For individuals needing minimal assistance. }\end{array}$ & $\begin{array}{l}\text { Employ PSWs to offer } \\
\text { light support to seniors } \\
\text { living in the facility. }\end{array}$ \\
\hline $\begin{array}{l}\text { Residential } \\
\text { care facilities }\end{array}$ & $\begin{array}{l}\text { Living facilities that also provide medical or personal } \\
\text { assistance to seniors. For those needing moderate } \\
\text { levels of assistance. }\end{array}$ & $\begin{array}{l}\text { Employ PSWs and } \\
\text { nurses. Doctors may be } \\
\text { available but are not } \\
\text { employed by every } \\
\text { facility. }\end{array}$ \\
\hline $\begin{array}{l}\text { Continuing } \\
\text { care }\end{array}$ & $\begin{array}{l}\text { Communities that provide various levels of living } \\
\text { assistance, from independent living to more intensive } \\
\text { medical care and assistance with daily tasks. Seniors } \\
\text { living in these communities can move between } \\
\text { different levels of care as they become more } \\
\text { dependent on others in their daily life. }\end{array}$ & $\begin{array}{l}\text { Employ PSWs and } \\
\text { nurses. Doctors may be } \\
\text { available but are not } \\
\text { employed by every } \\
\text { facility. }\end{array}$ \\
\hline Nursing homes & $\begin{array}{l}\text { Facilities that provide intensive medical care and } \\
\text { higher levels of assistance with eating, personal } \\
\text { hygiene, etc. These are focused on providing care for } \\
\text { very dependent patients and offer 24/7 assistance. }\end{array}$ & $\begin{array}{l}\text { Employ PSWs and } \\
\text { nurses. Doctors may be } \\
\text { available but are not } \\
\text { employed by every } \\
\text { facility. }\end{array}$ \\
\hline
\end{tabular}

Source: Based on information from the National Caregivers Library and Barken and Armstrong (2018)

frequently (JTFC, 2020). Issues cited include the misuse of personal protective equipment (PPE) by staff due to the lack of PPE available; insufficient staff training; a general lack of staff at the facilities; a lack in staff autonomy and agency; a lack of clinical skills; and overall failure to make Covid-19 protocols clear to staff (ibid.). The report offers examples of facilities employing new workers without providing adequate training and leaving workers to fend for themselves within the workplace with inadequate ratios and staffing numbers. Employees were often uninformed about appropriate safety measures and could not locate PPE supplies within the facilities or access them at all (ibid.). Despite its focus on five LTC facilities, the report highlights trends that were likely evident across Ontario LTC facilities. None of this was news to researchers and labour activists who had long lobbied for improved conditions. The province also took over the management of certain longterm care facilities (LTCF) that have reached critical levels in curbing Covid-19 outbreaks (Ministry of Long-Term Care, 2020). For example, Humber River Hospital assumed the management of Villa Colombo, a LTCF in North York (ibid.). This was done this on a temporary basis as a result of the management's failure to control the spread of Covid-19. 
These subsequent actions come as part of the government's response to Covid-19 outbreaks in LTCFs, including more funding to increase the number of LTC beds by 8000 , temporary wage increases of between $\$ 2$ and $\$ 3$ an hour for over 147,000 PSWs, and mandating employees only work at one LTC facility to reduce the risk of the spread of infection (Ontario Government COVID-19 Action Plan, 2020). Although increasing the number of beds is positive, the Ford government had previously cut proposed funding and bed increases (D'Mello, 2020). Moreover, the PSW pay increases are only temporary and staff have reported a loss of income as a result of the mandatory order to work at only one facility. These decisions are a delayed response to previous attempts at reducing support and funding for elder care, which proved detrimental to the Covid-19 response at LTCFs in Ontario. These shortcomings have been known to researchers for some time, with studies indicating there 'has been a persistence, if not intensification, in job precarity; inadequate staffing levels coupled with heavy workloads; routinised, assembly-line types of work; and cost-cutting on supplies' (Lowndes \& Struthers, 2017, 1). What is needed is a coherent plan to address understaffing (Ontario Health Coalition, 2020a, b). In a letter addressed to Ontario's LTC facilities, Deputy Minister of Long-Term Care Richard Steele writes, 'while we have all been focused on managing emerging crisis situations, as the course of the pandemic evolves, it is essential that there is a clear focus on returning all homes to a state of staffing stability' (CBC, 2020). However, the claim that LTC facilities in Ontario had staffing stability before this crisis carries little merit. Ontario's labour unions and activists have been reiterating the need to appropriately address the issues in LTC. Labour unions claimed the government's chronic underfunding of LTC has resulted in the current crisis and that in response ' $[\mathrm{t}]$ he government must mandate a permanent standardisation of pay to the top wage rates in the sector, full time schedules, improved access to benefits and adequate paid leaves for personal support workers' (Ontario Federation of Labour, 2020). Similarly, a CBC news report cited the president of SEIU Healthcare, a healthcare workers union, as saying that if the provincial government fails to make LTC staffing a priority, this crisis will not end (Brown, 2020).

Covid-19 has highlighted the care crisis that already existed in Ontario, throughout Canada, and across high-income nations; a crisis exacerbated by lack of regulation and increased encroachment of private interests. The provision of elder care is an issue of social justice and ethics and speaks to basic human rights and needs we all have as members of society. Increasingly, core nations have managed this social care policy issue by globalising their labour sourcing and incorporating migrant women into the sector. Immigration policies that reduce migrants' rights and intensify their vulnerability, together with increased privatisation and financialisation of the long-term care sector that reduces salaries and benefits, undermines the working conditions of those in LTC and has created conditions that serve neither those in need of care, nor those who provide it. As Armstrong et al. $(2020,7)$ state 'the conditions of work are the conditions of care'. The increased involvement of private interests is detrimental to LTC. Private companies cut costs to improve their bottom line, and the biggest expense is labour. The squeeze on labour has contributed to the deterioration of care as fewer workers are employed to deal with complex care 
needs, with less training and support. In this regard, we agree with Nancy Fraser's $(2016,99)$ contention that "the "crisis of care" is best interpreted as a more or less acute expression of the social reproductive contradictions of financialised capitalism'. Furthermore, in terms of policy responses, we support and contribute to the arguments already made by scholars and activists, that in terms of LTC, the conditions of work are the conditions of care (Block \& Dhunna, 2020). Any resolution of this social policy issue demands that we satisfy the needs of both the consumers of care (patients and their families) and the providers of care, who in many OECD nations are disproportionality women and immigrant women of colour.

Ai-Jen Poo (2020), the American labour activist and director of the National Domestic Workers Alliance, writes that historically, a zero-sum model has been utilised between families and care workers. The cost of care work has become interlinked with the ability of families to afford care for their elderly family members and that '[1] owering costs for families' necessities depressing wages for workers. Raising wages for workers means cutting services for families' (ibid.). However, as Poo and other labour activists highlight, this should not be the case: government intervention is necessary to address the issue of LTC financing in a way that best supports workers and, as a consequence, clients.

The following recommendations, based on expert opinion and governmentcommissioned reports, address the issues of labour and funding in the LTC sector (Armstrong et al., 2020; Romanow, 2002). First, workers' compensation in LTC facilities must be better regulated, ensuring that workers make a living wage that is commensurate with the valuable, difficult, and labour-intensive work they perform. Second, LTC workers should be hired into permanent full-time positions to allow workers access to employee rights and benefits and minimise the number of care workers employed at two or more LTC facilities. Third, care workers who enter the country as temporary migrants should be regularised to allow them increased access to Canadian and provincial employee rights and minimise their vulnerabilities to employer exploitation. Finally, LTC should be deemed a medically necessary criteria under the Canada Health Act, in line with the recommendations proposed by the 2002 Commission on the Future of Health Care in Canada (Romanow Commission).

Authors' Note We would like to thank Araba Maanan Blankson for research assistance. The writing of this chapter was supported through funding provided by the Social Sciences and Humanities Research Council and the Balsillie School of International Affairs.

\section{References}

Albertson Fineman, M. (2008). The vulnerable subject: Anchoring equality in the human condition. Yale JL \& Feminism, 20(1).

Armstrong, P., et al. (2020). Re-imagining long-term residential care in the COVID-19 crisis. Retrieved from Canadian Centre for Policy Alternatives website: https://www.policyalternatives.ca/publications/reports/re-imagining-long-term-residential-care-covid-19-crisis 
Armstrong, P., \& H. Armstrong (eds). (2019). The privatization of care: The case of nursing homes. Routledge.

Atanackovic, J., \& Bourgeault, I. L. (2013). The employment and recruitment of immigrant care workers in Canada. Canadian Public Policy, 39(2), 335-350. https://doi.org/10.3138/ cpp.39.2.335

Barken, R., \& Armstrong, P. (2017). Skills of workers in long-term residential care: Exploring complexities, challenges, and opportunities. Ageing International, 43(1), 110-122. https://doi. org/10.1007/s12126-017-9285-7

Barron, D. N., \& West, E. (2017). The quasi-market for adult residential care in the UK: Do for-profit, not-for-profit or public sector residential care and nursing homes provide better quality care? Social Science \& Medicine, 179, 137-146. https://doi.org/10.1016/j.socscimed.2017.02.037

Block, S., \& Dhunna, S. (2020). What does it cost to care? Canadian Centre for Policy Alternatives, June. https://www.policyalternatives.ca/sites/default/files/uploads/publications/Ontario\%20 Office/2020/06/Improving\%20care\%20in\%200ntario\%20LTC\%20facilities_final.pdf. Accessed 20 Aug 2020.

Browne, C. V., \& Braun, K. L. (2008). Globalization, women's migration, and the long-term-care workforce. The Gerontologist, 48(1), 16-24. https://doi.org/10.1093/geront/48.1.16

Brown, D. (2020). Province takes over Toronto long-term care home as premier pledges to spare no effort to protect residents. CBC News, 17 July. Retrieved from https://www.cbc.ca/news/ canada/toronto/humber-river-hospital-to-temporarily-manage-villa-colombo-1.5654652

Canadian Institute for Health Information. (n.d.) Residential care. Retrieved from https://www. cihi.ca/en/residential-care

CBC. (2020). Ontario asks long-term care homes for plan to stem the spread of COVID-19. https:// www.cbc.ca/news/canada/toronto/covid-ont-long-term-care-plan-1.5563934

Chevreul, K., \& Berg Brigham, K. (2013). Financing long-term care for frail elderly in France: The ghost reform. Health Policy, 111(3), 213-220. https://doi.org/10.1016/j.healthpol.2013.05.013

D'Mello, C. (2020). Ford's plan to build new long-term care beds is re-announcement of Liberal promise. CTV News, 16 July. Retrieved from https://toronto.ctvnews.ca/ford-s-plan-to-buildnew-long-term-care-beds-is-re-announcement-of-liberal-promise-1.5026793

The Economist. (2020). Special report on Dementia, 29 August.

Estabrooks, C. A., Squires, J. E., Carleton, H. L., Cummings, G. G., \& Norton, P. G. (2014). Who is looking after mom and dad? Unregulated workers in Canadian long-term care homes. Canadian Journal on Aging / La Revue canadienne du vieillissement, 34(1), 47-59. https://doi. org/10.1017/s0714980814000506

The Federal Ministry of Health (Germany). (2017). Peer review on “Germany's latest reforms of the long-term care system. Retrieved from OECD Publishing website: https://ec.europa.eu/ social/BlobServlet?docId=18962\&langId=en

Fraser, N. (2016). Contradictions of capital and care. New Left Review, 100(99), 99-117.

Gibson, V. (2019). 15,000 new long-term care beds won't reduce waitlist, says Ontario's Financial Accountability Office. iPolitics, 30 October. Retrieved from https://ipolitics. ca/2019/10/30/15000-new-long-term-care-beds-wont-reduce-waitlist-says-ontarios-financialaccountability-office/

Glinskaya, E., \& Feng, F. (2018). Options for aged care in. Building an Efficient and Sustainable Aged Care System. World Bank Publications. https://doi.org/10.1596/978-1-4648-1075-6

Goldring, L., \& Landolt, P. (2013). The conditionality of legal status and rights: Conceptualizing precarious non-citizenship in Canada. In Producing and negotiating non-citizenship: Precarious legal status in Canada (pp. 3-27). Press.

Government of Canada. (2014). Action for Seniors report. Retrieved from https://www.canada.ca/ en/employment-social-development/programs/seniors-action-report.html\#tc2

Government of Canada. (2020). Pathway to permanent residency recognizes exceptional service of asylum claimants on front lines of COVID-19 pandemic. Accessed 17 December 2020. https:// www.canada.ca/en/immigration-refugees-citizenship/news/2020/08/pathway-to-permanentresidency-recognizes-exceptional-service-of-asylum-claimants-on-front-lines-of-covid-19pandemic.html 
Hennebry, J., \& Walton-Roberts, M. (2019). Rebalancing act: Promoting an international research agenda on women migrant care workers' health and rights. A Research Agenda for Migration and Health, 88-106. https://doi.org/10.4337/9781786438362.00010

Hirdes, J., Declercq, A., Finne-Soveri, H., Fries, B. E., Geffen, L., Heckman, G., Lum, T., Meehan, B., Millar, N., \& Morris, J. N. (2020). The long-term care pandemic: International perspectives on COVID-19 and the future of nursing homes. Balsillie Papers, 15 July. https://www.balsillieschool.ca/wp-content/uploads/2020/07/Balsillie-Paper-Hirdes.pdf

Hochschild, A. R. (2015). Global care chains and emotional surplus value. Justice, Politics, and the Family, 249-261. https://doi.org/10.4324/9781315633794-21

Horton, A. (2019). Financialization and non-disposable women: Real estate, debt and labour in UK care homes. Environment and Planning A: Economy and Space. https://doi.org/10.117 $7 / 0308518 \times 19862580$

InterRAI. (n.d.). Organization. Retrieved from https://www.interrai.org/organization/

JTFC. (2020). OP LASER - JTFC observations in long-term care facilities in Ontario. Retrieved from Headquarters 4th Canadian Division - Joint Task Force (Central) website: https://www. macleans.ca/wp-content/uploads/2020/05/JTFC-Observations-in-LTCF-in-ON.pdf

Kelly, C., \& Bourgeault, I. (2015). The personal support worker program standard in Ontario: An alternative to self-regulation? Healthcare Policy| Politiques de Santé, 11(2), 20-26. https://doi. org/10.12927/hcpol.2016.24450

Lowndes, R., \& Struthers, J. (2017). Changes and continuities in the workplace of long-term residential care in Canada, 1970-2015. Journal of Canadian Studies, 50(2), 368-395.

Kofman, E. (2014). Towards a gendered evaluation of (highly) skilled immigration policies in Europe. International Migration, 52(3), 116-128.

Mezzadra, S., \& Neilson, B. (2013). Border as method, or, the multiplication of labor. Duke University Press.

Ministry of Long Term Care, Ontario. (2020). Hospital assumes management of Villa Colombo in North York. News Release, 17 July. https://news.ontario.ca/en/release/57645/ hospital-assumes-management-of-villa-colombo-in-north-york

Multicultural Meanderings. (2019). Public services and administration: What does the census say? Multicultural Meanderings, 27 May. Retrieved from https://multiculturalmeanderings. com/2019/05/27/public-services-and-administration-what-does-the-census-say/

Nadash, P., Doty, P., Mahoney, K. J., \& Von Schwanenflugel, M. (2011). European long-term care programs: Lessons for community living assistance services and supports? Health Services Research, 47(1pt1), 309-328. https://doi.org/10.1111/j.1475-6773.2011.01334.x

National Institute of Ageing. (n.d.) Long term care Covid-19 tracker. Accessed 17 December 2020. https://ltc-covid19-tracker.ca/.

OECD and European Union. (2013). Highlights from: A good life in old age? Monitoring and improving quality in long-term care. Retrieved from OECD Publishing website. https://www. oecd.org/els/health-systems/UnitedKingdom-OECD-EC-Good-Time-in-Old-Age.pdf

OECD. (2015). Health at a Glance 2015: OECD Indicators. Retrieved from OECD iLibrary website: https://doi.org/10.1787/health_glance-2015-en

OECD. (2019). Health at a Glance 2019: OECD Indicators. In OECD iLibrary. Retrieved from https://www.oecd-ilibrary.org/sites/4dd50c09-en/1/2/11/9/index.html?itemId=/content/ publication/4dd50c09-en\&mimeType $=$ text $/ \mathrm{html} \& \_c s p \_=82587932 \mathrm{df} 7 \mathrm{c06a6a3f} 9 \mathrm{dab} 9530409$ $5 \mathrm{~d} \&$ itemIGO=oecd\&itemContentType $=$ book

OLTCA. (n.d.). Facts and figures. Retrieved from https://www.oltca.com/oltca/OLTCA/ LongTermCare/OLTCA/Public/LongTermCare/FactsFigures.aspx ?hkey=f0b46620-90124b9b-b033-2ba6401334b4\#Ontario's\%20long-term\%20care\%20residents\%20(2015-2016)

Ontario Federation of Labour. (2020). OFL to Ford Government: Fix long-term care now. News release, 30 April. Retrieved from https://www.globenewswire.com/newsrelease/2020/04/30/2025915/0/en/OFL-to-Ford-Government-Fix-long-term-care-now.html

Ontario Government COVID-19 Action plan-Long term care homes. (2020). Accessed at https:// www.ontario.ca/page/covid-19-action-plan-long-term-care-homes\#section-0 
Ontario Health Coalition. (2020a). Hospital and long-term care health care workers \& long-term care residents infected with COVID-19. Update: 23 April. Retrieved from https://www.ontariohealthcoalition.ca/index.php/update-hospital-and-long-term-care-health-care-workers-longterm-care-residents-infected-with-covid-19-4/

Ontario Health Coalition. (2020b). COVID-19 death rates in Ontario long-term care homes significantly higher and increasing in for-profit homes vs. non-profit and publicly-owned homes: New data analysis. Release \& Analysis: 6 May. Retrieved from https://www.ontariohealthcoalition. ca/index.php/death-rates-in-long-term-care-by-ownership-release/

Ormond, M., \& Toyota, M. (2018). Rethinking care through transnational health and long-term care practices. In V. Crooks, G. Andrews, \& J. Pearce (Eds.), Routledge handbook of health geography (pp. 237-243). Routledge.

Ponder, C. S., Longhurst, A., \& McGregor, M. (2020). Contracting-out care: The socio-spatial politics of nursing home care at the intersection of British Columbia's labor, land, and capital markets. Environment and Planning C: Politics and Space, 2399654420960489.

Poo, A. J. (2020). Domestic workers: Building political power in the COVID era. Democracy Journal, 57, 1-9. Retrieved from https://democracyjournal.org/magazine/57/ domestic-workers-building-political-power-in-the-covid-era/

Raymond, T. (2020). Troops deployed to Ontario long-term care homes return from COVID deployment this week. CTV News, 21 June. Retrieved from https://ottawa.ctvnews.ca/troops-deployedto-ontario-long-term-care-homes-return-from-covid-deployment-this-week-1.4993434

Robillard, C., McLaughlin, J., Cole, D. C., Vasilevska, B., \& Gendron, R. (2018). 'Caught in the same webs' - Service providers' insights on gender-based and structural violence among female temporary foreign workers in Canada. Journal of International Migration and Integration, 19(3), 583-606. https://doi.org/10.1007/s12134-018-0563-3

Romanow, J. (2002). Building on values: The future of health care in Canada: Final report. Retrieved from Government of Canada website: http://publications.gc.ca/site/archiveearchived.html?url=http://publications.gc.ca/collections/Collection/CP32-85-2002E.pdf

Ruhs, M., \& Anderson, B. (2013). Responding to employers: Skills, shortages and sensible immigration policy. Europe's Immigration Challenge. https://doi.org/10.5040/9780755619931.ch-005

Saari, M., Patterson, E., Kelly, S., \& Tourangeau, A. E. (2018). The evolving role of the personal support worker in home care in Ontario, Canada. Health \& Social Care in the Community, 26(2), 240-249. https://doi.org/10.1111/hsc.12514

Seidle, F. L. (2020). Should Canada regularize the immigration status of asylum seekers helping fight COVID-19? Policy for Pandemics, 41. https://maxpolicy.substack.com/p/ issue-41-should-canada-regularize

Shutes, I. (2011). The employment of migrant workers in long-term care: Dynamics of choice and control. Journal of Social Policy, 41(1), 43-59. https://doi.org/10.1017/s0047279411000596

Sproule, L. (2020). Hospital and long-term care health care workers and long-term care residents infected with COVID-19: Updated March 30 2020. The Review, 31 March. Retrieved from https://thereview.ca/2020/03/31/hospital-and-long-term-care-health-care-workers-and-longterm-care-residents-infected-with-covid-19-updated-march-30-2020/

Turcotte, M., \& Savage, K. (2020). The contribution of immigrants and population groups designated as visible minorities to nurse aide, orderly and patient service associate occupations. Statistics Canada. Retrieved from: https://www150.statcan.gc.ca/n1/pub/45-28-0001/2020001/ article/00036-eng.htm

Vernon, T. (2020). Higher fees, more privatization highlight recommendations on Alberta's long-term care system. Global News, 21 February. Retrieved from https://globalnews.ca/ news/6581440/alberta-long-term-care-continuing-fees-privatization-ucp/

Walsh, M., \& Semeniuk, I. (2020). Long-term care connected to 79 per cent of COVID-19 deaths in Canada. The Globe and Mail, 28 April. Retrieved from https://www.theglobeandmail.com/ politics/article-long-term-care-connected-to-79-per-cent-of-covid-19-deaths-in-canada/ 
World Health Organization. (2002). Ethical choices in long-term care: What does justice require? World Health Organization. https://www.who.int/mediacentre/news/notes/ethical_choices.pdf World Health Organization. (2017). Women on the move: Migration, care work and health. Retrieved from https://apps.who.int/iris/bitstream/handle/10665/259463/9789241513142-eng.pdf

Yeates, N. (2009). Globalizing care economies and migrant workers: Explorations in global care chains. Palgrave Macmillan.

Yeates, N. (2011). Going global: The transnationalization of care. Development and Change, 42(4), 1109-1130. https://doi.org/10.1111/j.1467-7660.2011.01718.x

Open Access This chapter is licensed under the terms of the Creative Commons Attribution 4.0 International License (http://creativecommons.org/licenses/by/4.0/), which permits use, sharing, adaptation, distribution and reproduction in any medium or format, as long as you give appropriate credit to the original author(s) and the source, provide a link to the Creative Commons license and indicate if changes were made.

The images or other third party material in this chapter are included in the chapter's Creative Commons license, unless indicated otherwise in a credit line to the material. If material is not included in the chapter's Creative Commons license and your intended use is not permitted by statutory regulation or exceeds the permitted use, you will need to obtain permission directly from the copyright holder.

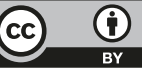

